\title{
Event Marketing as an Effective Tool for Building Long-Term Customer Relationships
}

\author{
N.S. Sharafutdinova \\ Marketing department \\ Kazan Federal University \\ Kazan, Russia \\ Natabell22@mail.ru \\ N.G. Xametova \\ Marketing department \\ Kazan Federal University \\ Kazan, Russia \\ hametova_ng@mail.ru
}

\author{
E.N. Novikova \\ Marketing department \\ Kazan Federal University \\ Kazan, Russia \\ novelena@list.ru
}

\author{
Zh. P.Shnorr \\ Chair of Business in Service Sector \\ Novosibirsk State University of \\ Economics and Management \\ Novosibirsk, Russia \\ Shnorr75@mail.ru
}

\author{
E.S. Rolbina \\ Marketing department \\ Kazan Federal University \\ Kazan, Russia \\ rolbinaes@mail.ru
}

\begin{abstract}
The article discusses the main trends in the development of event marketing in Russia. Based on a comprehensive analysis of event marketing effectiveness assessment approaches, the authors proposed a methodology for event marketing performance assessment that takes into account several indicators: the degree of satisfaction of participants, the level of interactions with potential customers, the number of test trips conducted, the event marketing multiplier, return on investment, psychological type of consumer, efficiency criteria of product promotion. The author's approach consists in comprehensively studying the effectiveness of event marketing. The effectiveness of event marketing evaluates the change in consumer attitudes to the brand and products; the established emotional relationship forms a stable perception of the brand values, which is expressed in a positive perception of the company, in its recognition, in relation to it [1].

Testing the proposed methodology has proven the practical application of the proposed approach for evaluating the effectiveness of event marketing [2]. The performance indicators proposed by the author made it possible to evaluate event marketing, while the key aspect - the emotional connection with the consumer remains crucial [3].

A survey of participants in the event led to the conclusion that the event le $\mathrm{ft}$ positive impressions and emotions in the minds of the participants, and economic calculations confirmed its economic efficiency.
\end{abstract}

Keywords: event marketing, customer relationship, evaluation of the effectiveness of event marketing, promotion

\section{INTRODUCTION}

In modern realities, in pursuit of a client, companies are trying to form a concept of doing business that will attract new customers and maintain the loyalty of existing customers. The concept of event marketing helps in solving such problems.

Event marketing is aimed at the emotional affection of the potential consumer to the brand. This connection is a more reliable communication between the manufacturer and the consumer, which determines the growing interest in event marketing [4].
Among the main areas of event marketing today, the following can be distinguished:

1) annual meetings in major cities of the world or on exotic islands are hold by senior managers in order to form strategic development plans for the company;

2) presentations of a new product or service. In this context, you can consider events in the framework of product promotion or global events in the framework of national tours [2];

3) training for employees and the presentation of motivational programs. The substantial budget and original implementation make this direction one of the main factors in the internal development of the company;

4) image events. In this case, we consider one-time or regular events in order to increase the image of the company [4].

The main conditions that stimulate the development of the event marketing market in present reality:

- increase in spending on company's marketing activities;

- company's orientation to use marketing activity tools, which cause a long-term emotional connection with the brand;

- consumer interest in participating in events organized by various major brands [5];

- social orientation of event marketing stimulates the participation of various partners in the events, which makes them even more attractive and significant;

- popularization of marketing activities in various directions;

- state policy in various fields of activity, which regulates the use of certain means of marketing communications.

Russian event services market has begun to expand rapidly over the past three years. Today, new companies enter the market providing event management services. 
- $0,4 \leq E_{1} \leq 0,6$ - ineffective;

Accordingly, the quality of provided services goes up, and fierce competition in the market requires more and more creative ideas from the company providing this type of service. Customers prefer companies that offer the most interesting scenario for the event, containing not only entertainment, but also a semantic meaning.

Significant development of the advertising production base, an increase in the range of advertising and souvenir products contributes to the bright design of the corporate event.

The range of entertainment offered has grown significantly. Recently, corporate events have been held mainly by large international companies. In the future, domestic companies will actively use the opportunities of the event market [6]. The event marketing market is also influenced by the development of Internet technologies and social media [7].

\section{OBJECTS AND METHODS OF RESEARCH}

We further develop a methodology for evaluating the effectiveness of event marketing based on a comprehensive analysis of the approaches to assessing the effectiveness of event marketing proposed by other scholars. Proposed technique is based on the calculation of the following indicators: participants' degree of satisfaction, level of interaction with potential customers, number of test drives conducted, event marketing multiplier, return on investment, consumer psychological type, product promotion effectiveness criteria.

The effectiveness of event marketing is a comprehensive indicator designed to give a comparative assessment between the actual and the expected result of the marketing event implementation, as well as to consider the change in relation to the perception of brand values by an individual. The effectiveness of event marketing represents a change in the consumer perception of the brand. The proposed approach characterized by complexity of studying the event marketing effectiveness.

Event marketing organization algorithm.

1. Organizing a special event, following all the steps listed below.

2. Collection of information by interviewing event marketing participants using a questionnaire.

3. Analysis of the received information.

We propose the following system of indicators to assess the event marketing effectiveness.

1. The result

$$
\mathrm{E}_{1}=\frac{\mathrm{S}_{3}}{\mathrm{~S}_{\mathrm{s}}}
$$

$\mathrm{S}_{3}$, - sales in the third month after the marketing event, $\mathrm{S}_{\mathrm{s}}$ - sales in the month of the event. Only sales to event participants are considered here.

The scale for evaluating the effectiveness of the indicator $\mathrm{E}_{1}[0 ; 1]$

- $E_{1} \leq 0,3$ - effective;
- $E_{1} \geq 0,7-$ inefficient.

2. Number of purchases

$$
\mathrm{E}_{2}=\frac{S}{N} \times 100 \%
$$

$\mathrm{E}_{1} \leq 0.3$ - effective;

$0.4 \leq \mathrm{E}_{1} \leq 0.6$ - ineffective;

$\mathrm{E}_{1} \geq 0.7$ - inefficient

3. Number of purchases

$$
E_{2}=\frac{S}{N} \times 100 \%
$$

$\mathrm{S}$ is the number of purchases, $\mathrm{N}$ is the number of participants in the marketing event. $\mathrm{E}_{2}$

The scale for evaluating the effectiveness of the indicator

- $\mathrm{E}_{2} \leq 9 \%$ inefficient;

- $\mathrm{E}_{2} \geq 10 \%$ - effective.

4. Brand recognition

$$
E_{3}=\Delta K_{n}
$$

where $\Delta K_{n}$ is the change in brand recognition, which is evaluated as a result of a survey. $\mathrm{E}_{3}:$

The scale for evaluating the effectiveness of the indicator

- $\mathrm{E}_{3} \geq 15 \%$ - effective;

- $\mathrm{E}_{3} \leq 14 \%$ - inefficient.

5. Return on investment

$$
E_{4}=\frac{R-I}{I} \times 100 \%
$$

where I - the costs of organizing a marketing event; R income from marketing events.

The scale for evaluating the effectiveness of indicator $\mathrm{E}_{4}$ :

- $\mathrm{E}_{4} \leq 39 \%$ - inefficient;

- $40 \leq \mathrm{E}_{4} \leq 74 \%$ - ineffective;

- $\mathrm{E}_{4} \geq 75 \%$ - effective.

So, the event can be considered:

Ineffective if one condition is met, or none.

An event can be considered effective if 2-3 conditions are met.

An event can be considered highly effective if all 4 conditions are met, namely: 


$$
E_{1} \leq 0.3 ; E_{2} \geq 10 \% ; E_{3} \geq 15 \% ; E_{4} \geq 65 \%
$$

The effectiveness of event marketing is assessed as a change in consumer attitudes towards the brand and products. The established emotional relationship forms a stable perception of brand values, which is expressed in a positive perception of the company, in the degree of its recognition. The consumer perceives the marketing event as rational and useful. At the same time, event marketing allows consumer to feel ownership of the brand's history and its exclusivity, which is especially evident in events that are implemented for premium brands [8].

Proposed indicators allow evaluating event marketing, while the key aspect remains the emotional connection with the consumer. Thus, the impact of event marketing occurs in the field of personal motives and values of the individual, in accordance with which an effective communication strategy is built.

Therefore, at present, event marketing is a relevant, effective tool for brand communication with consumers, which allows influencing the emotional perception of the target audience. The key and fundamental advantage of this communication is its attractiveness to the consumer, built on the motives of curiosity, interest, acquisition of new experience, and desire to have fun and relax, whereas engaging in the communication process is voluntary. Event marketing is becoming one of the most effective tools for brand communication with the consumer and, creating additional brand value in the mind of the buyer [9]. The effect of corporate social responsibility image on perceived brand distinctiveness was strongest for cause-related event marketing, followed by cause-related experiential marketing, transaction-based CRM and sponsorship-linked marketing [1].

The purpose of the study is to evaluate the effectiveness of event marketing. Within the framework of the goal, the following tasks were set: to develop an algorithm for evaluating the effectiveness of event marketing, to test the proposed methodology on the example of a particular company, to formulate relevant conclusions.

\section{RESULTS AND DISCUSSION}

The context of the study is LLC Gentls Group. The company is a franchisee of men's jewelry and accessories shops. The company has been operating in the market since 2013.

The main assortment positions at present are:

- Men's bracelets;

- Men's rings;

- Neck jewelry (chains, chokers, pendants, pendants for two);

- Men's earrings;

- Cufflinks;

- Sets of jewelry;

- Accessories (ties and bowties, scarves, tie clips, purses and wallets, key holders, belts, card holders);

- Document covers.
Potential consumers of the Gentls Group LLC products are a fairly broad target segment of men who value their appearance and have an average income level.

TABLE I. THE MAIN TARGET SEGMENTS OF THE CONSUMER MARKET OF MEN'S JEWELRY AND ACCESSORIES OF GENTLS GROUP LLC

\begin{tabular}{|l|l|}
\hline \multicolumn{1}{|c|}{$\begin{array}{c}\text { Target segment of the } \\
\text { consumer market }\end{array}$} & \multicolumn{1}{|c|}{$\begin{array}{c}\text { Features of the target segment of the } \\
\text { consumer market }\end{array}$} \\
\hline $\begin{array}{l}\text { 1. Men who value their style, } \\
\text { appearance }\end{array}$ & $\begin{array}{l}\text { Part of the business community, the elite } \\
\text { of civil servants, part of students and } \\
\text { office workers }\end{array}$ \\
\hline $\begin{array}{l}\text { 2. Wives /girlfriends/ lovers } \\
\text { of men who value their style }\end{array}$ & $\begin{array}{l}\text { Target segment focused on the choice of } \\
\text { personalized gifts }\end{array}$ \\
\hline 3. Women co-workers & $\begin{array}{l}\text { Target segment of standardized holiday } \\
\text { gifts for men (February 23, New Year, } \\
\text { company days, etc.) }\end{array}$ \\
\hline $\begin{array}{l}\text { 4. Representatives of the } \\
\text { rocker/biker culture }\end{array}$ & $\begin{array}{l}\text { A stable segment, focused on the } \\
\text { relatively intensive consumption of } \\
\text { relatively cheap accessories and jewelry }\end{array}$ \\
\hline 5. Collectors & $\begin{array}{l}\text { A narrow segment focused on the } \\
\text { acquisition of a wide range of products }\end{array}$ \\
\hline
\end{tabular}

At the same time, some of the Gentls Group LLC's products is also oriented towards the relatively low-income segment of the market.

The growth in total revenue from product sales $(307.8 \%)$ is the evidence of the Gentls Group LLC's success in the market for men's jewelry.

This high growth rate was to some extent caused by Gentls Group LLC's rather aggressive marketing policy, and serving diverse target segments for fashion men's jewelry: selling both relatively expensive jewelry containing precious metals, and one designed for a relatively low income level.

TABLE II. THE MAIN INDICATORS OF GENTLS GROUP LLC'S FINANCIAL AND ECONOMIC ACTIVITY, THOUSAND RUBLES

\begin{tabular}{|l|l|l|l|l|}
\hline \multicolumn{1}{|c|}{ Name of indicator } & $\mathbf{2 0 1 6}$ & $\mathbf{2 0 1 7}$ & $\mathbf{2 0 1 8}$ & $\begin{array}{c}\text { Growth } \\
\text { rate, 2018 } \\
\text { to 2016,\% }\end{array}$ \\
\hline 1. Revenues & 14179 & 27843 & 43654 & 307.8 \\
\hline 2. Profit from sales & 5678 & 13451 & 22311 & 392.9 \\
\hline 3. Net profit & 3291 & 904 & 18983 & 576.8 \\
\hline $\begin{array}{l}\text { 4. The residual value } \\
\text { of fixed capital }\end{array}$ & 1411 & 1560 & 1670 & 118.3 \\
\hline $\begin{array}{l}\text { 5. Loans and } \\
\text { borrowings }\end{array}$ & 1905 & 1002 & 1400 & 73.4 \\
\hline
\end{tabular}

The proceeds from the sale of franchises in 2018 amounted to $17.8 \%$ of the total revenue of the organization.

At the same time, at the end of 2018 - the first quarter of 2019, revenue growth slowed somewhat, which indicates a high likelihood of Gentls Group LLC's entry into the maturity stage of the life cycle in the medium term.

Currently, the main competitor of Gentls Group LLC in the men's jewelry market is the Spikes brand. A feature of the marketing development of Gentls Group LLC is the active use of customer-oriented marketing:

- active work with the company's website visitors [8];

- substantial range of discounts [4]; 
- offers for wholesale customers, differentiated both by the size of the bulk order and by its assortment breadth;

- marketing campaigns for buyers of the franchise LLC Gentls Group, certain franchise guarantees;

- e-mail marketing is being introduced;

- conducting event marketing.

As part of the study, a methodology for evaluating the effectiveness of event marketing was tested.

The first step was a survey among the event participants. A questionnaire was developed in order to assess the effectiveness of the event. Gentls club cards were offered as an incentive to fill out the questionnaire.

During the event, 67 questionnaires were filled out, including 55 men and 12 women. Age of participants was in the range from 26 to 34 years. When asked if the event was pleasant, only one of the respondents gave a negative answer. This suggests that the event left positive emotions for almost all festival participants. Positive emotions give rise to a confidence in the product and brand, accelerate purchase decision.

The following questions were asked in order to find out if this festival affected the recognition of the Gentls store for men's jewelry and accessories. According to the results of the survey, it turned out that 61 people were familiar with the store of men's jewelry and accessories, and 6 people were not familiar. Those survey participants who answered the question positively answered the additional question: "Have you known about the Gentls men's jewelry and accessories store until today?" It turned out that before the event, 50 people knew about the store, and 11 people found out on the day of the festival.

The survey participants' willingness to fill out a questionnaire in order to receive a club card indicates their intention to make a purchase at the Gentls store.

Further economic indicators were calculated to assess the effectiveness of the event:

1. The first indicator is the ratio of purchases in the third month after the festival to the number of purchases per month of the festival.

$E_{1}=7387 / 16788=0.44$ (for this indicator, the event can be considered ineffective, because this indicator falls into the range $0.4 \leq \mathrm{E}_{1} \leq 0.6$ ).

2. The second indicator is the number of purchases.

$\mathrm{E}_{2}=16 / 98 \times 100=16.32$

$16.32 \% \geq 10 \%$ (for this indicator, the event can be considered effective).

\section{Brand recognition.}

According to the results of the survey, this indicator was $15 \%$, this suggests that the event can be considered effective for this indicator.

4. Return on investment.

$\mathrm{E}_{4}=(19054-10398) / 10398 \times 100 \%=182.4$

For this indicator, the event can be considered effective.
In total, it turns out that out of all four performance indicators three conditions are fulfilled, which means that this event was effective.

\section{CONCLUSION}

The effectiveness of event marketing is aimed at assessing changes in consumer attitudes to brands and products. The established emotional relationship forms a stable perception of brand values, which is expressed in a positive perception of the company, in its recognition.

The proposed performance indicators made it possible to evaluate event marketing, while the key aspect remains the emotional connection with the consumer.

A survey of participants in the event led to the conclusion that the event left positive impressions and emotions in the minds of the participants, and economic calculations confirmed its economic efficiency.

Any event, even the most interesting and unusual in its idea, can come to naught due to poor-quality planning and implementation. A specially organized event is a process that requires a lot of labor, time, and in the absence of sponsors, also financial resources. Therefore, it is worthwhile to approach the organization of the event very carefully: plan it in a high-quality manner, find professional event managers and attract as many sponsors and the media as possible [10].

Event marketing is a new format for companies to promote their products and services. The popularity of this direction is due to its effectiveness. The main task is to arouse the positive emotions of a potential buyer by immersing him in the world of the brand. The result is influenced by many factors, such as the choice of the type of event, the originality of the idea, advertising support, as well as technical issues [3].

A well-organized event allows you to increase the circle of consumers and sales of goods and services. Organization of events is a long-term and complex process, the success of which is affected by a large number of different factors that must be taken into account [6].

\section{REFERENCES}

[1] C. Coppeneur-Gülz and R. Sven-Volker, "Event-ResourceManagement mit digitalen Tools," Springer Gabler, Wiesbaden, Springer Fachmedien Wiesbaden $\mathrm{GmbH}$, ein Teil von Springer Nature, 2018. DOI: https://doi.org/10.1007/978-3-658-22331-1.

[2] A. Abdo Harb, D. Fowler, H. Jung (Julie) Chang, S. C. Blum, and W. Alakaleek, "Social media as a marketing tool for events," Journal of Hospitality and Tourism Technology, vol. 10, iss. 1, 2019 pp.2844. DOI: https://doi.org/10.1108/JHTT-03-2017-0027.

[3] Ji Young Lee and Kim K.P. Johnson, "Cause-related marketing strategy types: assessing their relative effectiveness," Journal of Fashion Marketing and Management: An International Journal, 2019. DOI: https://doi.org/10.1108/JFMM-03-2018-0032.

[4] E. S. Rolbina, E. N. Novikova, N. S. Sharafutdinova, O. V. Martynova, "The study of consumer loyalty services," Ad AltaJournal of Interdisciplinary Research, vol. 7, iss. 2, 2017, pp. 248253.

[5] A. G. Close, R. Z. Finney, and J. Z. Sneath, "Engaging the consumer through event marketing: Linking attendees with the sponsor, community and brand," J. of Advertising Research, December 2007, pp. $420-433$.

[6] D. V. Chernova, N. S. Sharafutdinova, E. N. Novikova and all, "Evaluation of Event Marketing in IT Companies," Lecture Notes in Networks and Systems,. vol. 84, 2020, pp. 487-493.

[7] A. Liu, X. Liu, and X. Huang, "A statistical approach to participant selection in location-based social networks for offline event 
[10] H. Syhre and S. Luppold, "Event-Technik. Technisches Basiswissen marketing," Information Sciences, vol. 480, 2019, pp. 90-108. DOI https://doi.org/10.1016/j.ins.2018.12.028.

[8] N. Sharafutdinova and J. Valeeva, "Quality management system as a tool for intensive development of trade organizations," Mediterranean Journal of Social Sciences, 6 (1S3), 2015, 498 p.

[9] L. Liu , J. Zhang, and H. T. Keh, "Event-marketing and advertising expenditures: The differential effects on brand value and company revenue," Journal of Advertising Research, 58 (4), 2018, pp. 464-475. DOI: https://doi.org/10.2501/JAR-2017-043. für erfolgreiche Veranstaltungen," Gabler Verlag, IX, 2018, 75 p. DOI: https://doi.org/10.1007/978-3-658-19798-8. 